UDC 621.8

DOI: $10.25140 / 2411-5363-2020-3(21)-112-119$

\author{
Semjon Jan, Martin Fufal, Martin Kocan
}

\title{
DESIGN OF THE HANDLING PROCESS AT THE WORKPLACE WITH ABB ROBOT AND MODULAR CONVEYOR
}

Urgency of the research. The use of robotic Pick \& Place operations in industry is currently gaining in importance due to increasing productivity in the workplace. Deployment of such robotic workplaces in the food industry, where it is necessary to handle a large number of products, allows to maintain the competitiveness of the producers of these products. The ability to carry out demonstrations and trainings at workplaces that are not directly part of production allows students and workers to try out these processes without the need to shut down production.

Target setting. The aim is to design a functional workplace, whose task will be to implement demonstrations of work in a robotic workplace. The designed workplace will also serve in the educational process, where students will have the opportunity to improve their knowledge in programming Pick \& Place tasks using a parallel robot. At the same time, students will be able to program the logic of pallet movement on a modular conveyor and synchronize this movement with the robot's movement.

Actual scientific researches and issues analysis. Automation or robotization would not be possible without the use of modern conveyor systems. Therefore, it is necessary to constantly try to modify the currently used systems so as to increase their productivity while maintaining the required quality. This can be achieved not only by optimizing processes, but also by using modern modular conveyor systems.

Uninvestigated parts of general matters defining. Increasing the competence of employees and students in the programming of robotic workplaces improves their application on the labour market. This cannot be achieved only by theoretical preparation, it is necessary to have real training workplaces equipped with appropriate technology.

The research objective. The aim was to design such a robotic workplace where it will be possible to increase the potential of employees or students and develop their creative thinking. The use of the proposed objects for manipulation has only a demonstration task and assumes that students will come up with their own design solution to the given problem during the training process.

The statement of basic materials. Deployment of parallel robots in various operations has an ever-increasing trend. The preparation of suitable workers for the optimal use of such robotic workplaces is therefore also important due to the transition to Industry 4.0 .

Conclusions. The article describes the modification of a modular conveyor for the needs of a robotic workplace equipped with a parallel robot. The workplace is equipped with an IRB 360/3 - 1130 robot, a Bosch modular conveyor equipped with pallets and a belt conveyor of its own production. The parallel robot is equipped with a suction cup enabling the removal of parts weighing up to $300 \mathrm{~g}$. The proposed handling process envisages the transfer of cube-shaped parts from a modular conveyor to a belt conveyor. When designing the workplace, it was necessary to replace the damaged control unit in the modular conveyor, equip the conveyor with a system of additional sensors and program the workplace. The proposed workplace will serve as a demonstration workplace on the university, as well as for training students in programming robots and a modular conveyor.

Keywords: robot; programming; conveyor; palette.

Fig.: 9. Table: 1. References: 8.

Problem definition. The trend of robotics (automation in general) is the cause of everincreasing demands for increasing production and production quality. There are many manufacturers on the market with a rich history who deal with the issue of robotics and offer a full range of industrial robots designed for different types of tasks. Robotic workplaces often use parallel (delta) robots to quickly pick up smaller products and organize them (Picking and Placing). Despite the relatively simple design, they can work with high speed, acceleration and accuracy $[1,2]$. The aim of the article is to design a handling process for the Delta robot ABB IRB 360 FlexPicker using a modular conveyor belt and at the same time to design a reconstruction of this conveyor for the successful execution of the process.

The idea to create a new robot was created in the late 1980s by Swiss professor Reymond Clavel and his team from the Laboratory of Robotic Systems at the Ecole Polytechnique Federale de Lausanne (EPFL). Professor Clavel was looking for repetitive robot jobs, and after visiting a chocolate praline factory, they discovered that chocolate praline packaging was a candidate for this type of high-speed, low-payload automation. There were also few robots on the market that could quickly and repeatedly perform Pick \& Place tasks. The professors' team began to set restrictions on the design of the robot. First, the robot had to perform up to 3 operations per second. For the correct placement of the chocolate, the mobility of the robot required 4 degrees of freedom: translation along 3 axes, as well as rotation around the vertical axis. To achieve a high level of productivity, Clavel designed to position the motors and all robot controls so that they are attached to the frame and make the moving part of the robot as ( Семйон Ян, Фуфал Мартін, Кочан Мартін, 2020 
TECHNICAL SCIENCES AND TECHNOLOGIES

easy as possible. This mechanism led to the creation of a robot with a delta structure [3]. Little did anyone know that at the turn of the century, this mechanism would be used as one of the most successful parallel mechanisms with several hundred active robots around the world.

Current status in workplace. ABB Flexible Automation started manufacturing delta robots in 1999 under the name IRB 340 FlexPicker. This type of robot was primarily to be used in three industries - the food, pharmaceutical and electronics industries.

There is an industrial robot IRB 360-3 / 1130 at the workplace, Fig. 1 equipped with suction cups, a Bosch modular conveyor and a self-made belt conveyor.
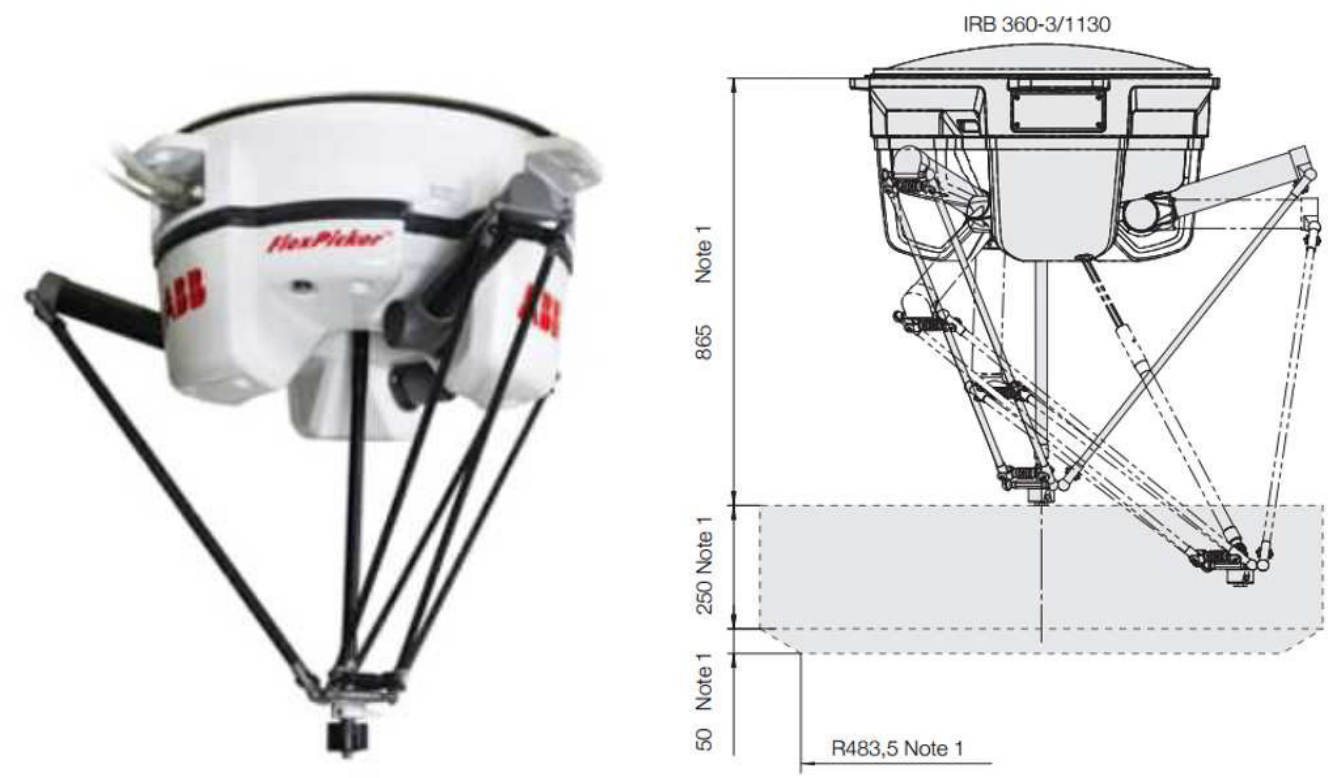

Fig. 1. Robot ABB IRB 360

The IRB 360 robot group includes variants with a load capacity of $1 \mathrm{~kg}, 3 \mathrm{~kg}, 6 \mathrm{~kg}$ and $8 \mathrm{~kg}$ and with a reach of $800 \mathrm{~mm}, 1,130 \mathrm{~mm}$ and $1,600 \mathrm{~mm}$ - which means that the IRB 360 is available for versatile use depending on the required requirements. Thanks to good motion control, short cycle times and high accuracy, the IRB 360 can work with small tolerances at very high speeds, whether in narrow or wider spaces [4]. Each FlexPicker also has a sophisticated tool flange that allows the use of a larger gripper and thus achieves higher speed when handling continuously packaged products from a moving belt. The parameters of the robot are given in Table.

Table

$A B B$ robot parameters [5]

\begin{tabular}{|c|c|}
\hline Weight & $120 \mathrm{~kg}$ \\
\hline Payload & $3 \mathrm{~kg}$ \\
\hline Working range & $1130 \mathrm{~mm}$ \\
\hline Cycle times & $0.52 \mathrm{~s}$ \\
\hline Repeatability & $+/-0.1 \mathrm{~mm}$ \\
\hline
\end{tabular}

Modular pallet conveyor (TS1) is part of a larger family of TS (Transfer Systems) from Bosch Rexroth, which also includes TS plus and TS4 plus [5]. Like all TS products, the TS 1 is a nonsynchronous conveyor based on the movement of pallets carrying workpieces, which is designed to increase production productivity, time efficiency and at the same time allows flexibility in assembly. All TS 1 components are pre-prepared and modular. This means that additional modules can be combined or added as required. The system can be easily changed, reconfigured or relocated as needed. As production requirements change, TS 1 provides the flexibility to add manual or automatic workstations. Popularity also simplifies system design and installation. As 
a result, it can better respond to changing task requirements. Installation and maintenance are also simple [6]. At the workplace in the TUKE laboratory, a parallel conveyor was used, the model of which is shown in Fig. 2. The dimensions of the conveyor are $3500 \times 600 \times 900 \mathrm{~mm}$.

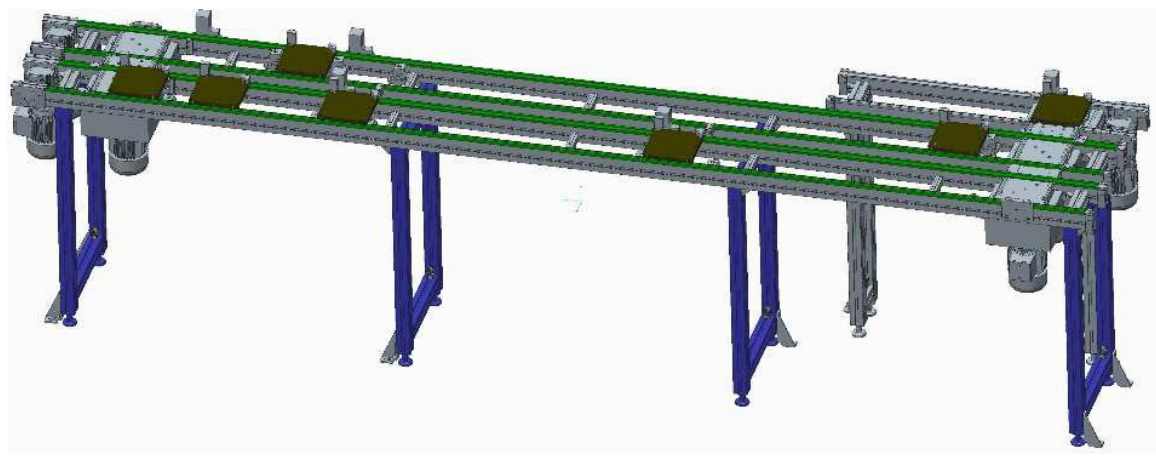

Fig. 2. Modular conveyor

TS 1 conveyors transport parts on pallets of workpieces. Workpiece pallets travel on conveyor conveyor belts. The pallets can be stopped at the front or rear edge - regardless of the orientation of the pallet on the conveyor. Pallets can also be stacked in a queue and released one at a time. The size of the pallet is $160 \times 160 \mathrm{~mm}$ and the load capacity is $3 \mathrm{~kg}$.

The belt conveyor has dimensions of $2015 \times 550 \times 900 \mathrm{~mm}$. The width of the belt is $300 \mathrm{~mm}$

Proposal of robotized workplace. The modular conveyor used at the workplace in the KVTaR SjF TUKE laboratory must undergo several modifications in order to be suitable for use in the proposed handling process. Priority must be given to replacing the non-functional original PLC responsible for the conveyor logic. Subsequently, the conveyor must be equipped with sensors and pneumatic stop gates to a predetermined location and connected correctly. The original Siemens S7 / 300 automatic machine, which was responsible for the control of the conveyor belt, is inoperative and therefore needs to be replaced. The same PLC model (S7 / 300) is used as a substitute [7]. Replacing the PLC is very important, because the PLC will be responsible in the handling process for the complete control of the conveyor and also for sending signals to the control system of the IRC5 robot. These signals allow the IRB 360 robot to be started and manipulated.

The design of the conveyor conversion must be further extended to include inductive sensors. The first task that these sensors will perform is to identify the pallet with the product before the place of gripping the product and subsequent handling, Fig. 3a. This sensor will trigger the stop gate. The pneumatic stop gate stops the pallet with the product under the place of handling, thus preventing its movement, Fig. 3b. The robot can then grab the product and move it. After the product is picked up by the robot, the stop gate is deactivated and the empty pallet continues on its way, Fig. 3c. The sensor and the corresponding stop gate thus wait for the next cycle with the pallet and the product.

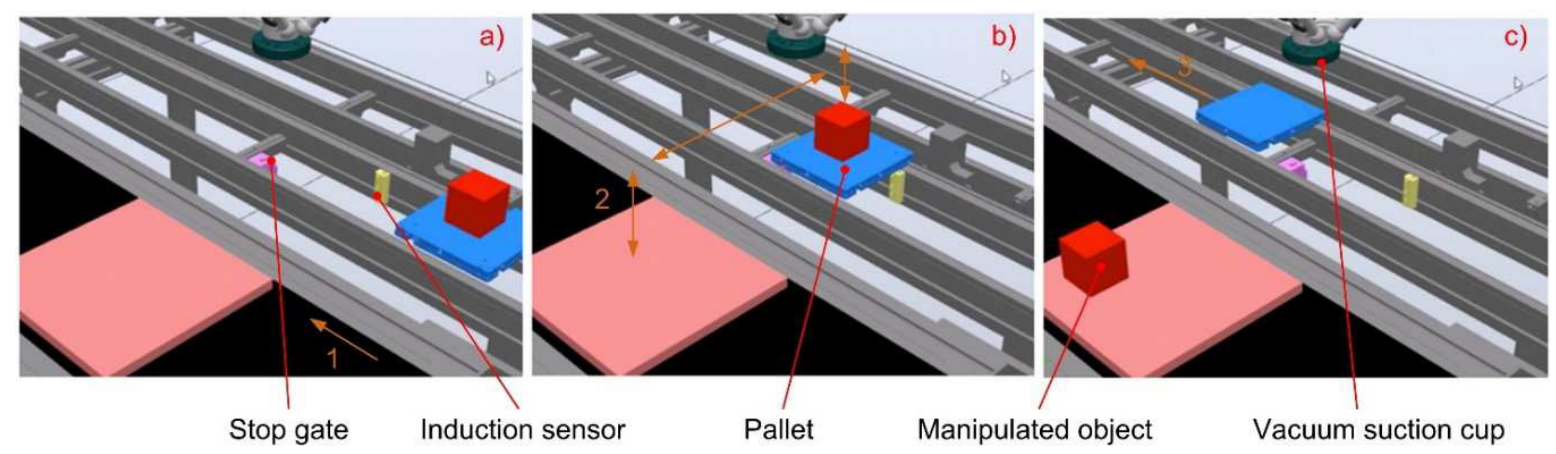

Fig. 3. Manipulation process 
TECHNICAL SCIENCES AND TECHNOLOGIES

The first stop gate located in front of the cross conveyor is deactivated after the start of the process, thus allowing the movement of the first pallet with the product. The following sensor is responsible for activating the stroke of the cross conveyor, during which the pallet is raised and thus allows the pallet to be moved between the two paths, Fig. 4a. The lifting takes place after a time delay which allows the pallet to reach the guide tracks of the cross conveyor. After moving the pallet to the desired position, the stroke of the transverse conveyor is deactivated and the pallet thus reaches the path of the longitudinal conveyor, along which it starts to move, Fig. 4b. The following sensor, which has detected a pallet that has passed through the cross conveyor, deactivates the stop gate preventing the pallet from moving in front of the cross conveyor, Fig. 4c. This will allow the next pallet to move and cross the cross conveyor.

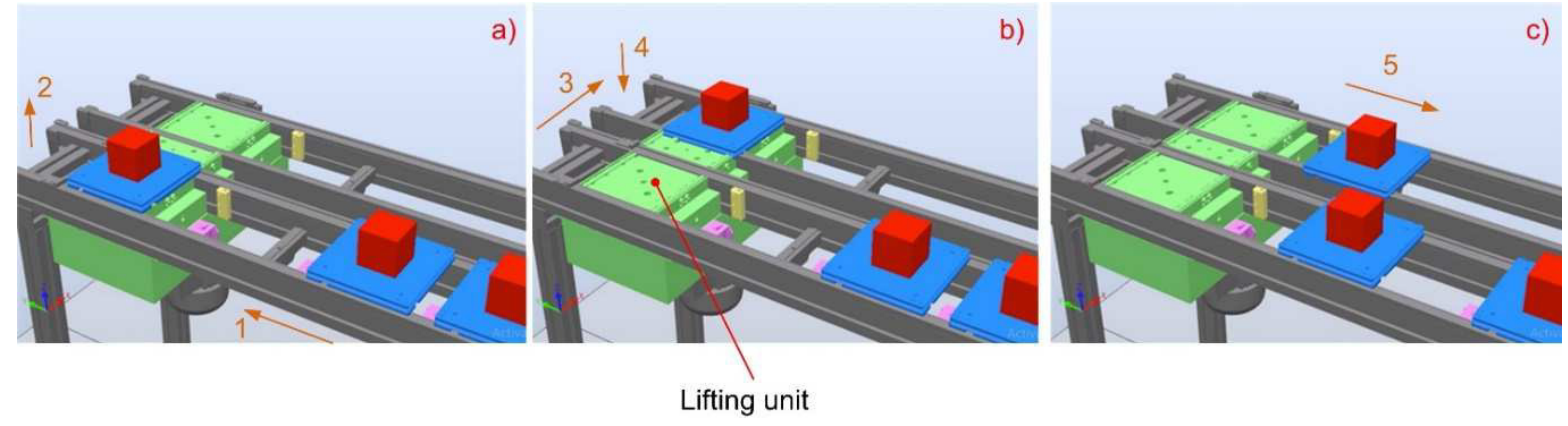

Fig. 4. Moving pallets between two conveyors

Based on the analysis of the possibility of solving the movement of pallets on the conveyor, the Pick \& Place process was designed on a robotic workplace. The design was implemented in the ABB Robot Studio environment. In the initial position, the stops are activated, which hold 4 pallets, while the initial position of the pallets and the products located on them is shown in Fig. 5a. The process begins with the start of the drives of the longitudinal and transverse conveyors. Then the whole process starts, using Flexpendant (we start the program). The pallets are gradually moved through the transverse conveyor under the place of handling, where the robot moves the product located on the pallet and places it in a predetermined position, Fig. $5 \mathrm{~b}$.
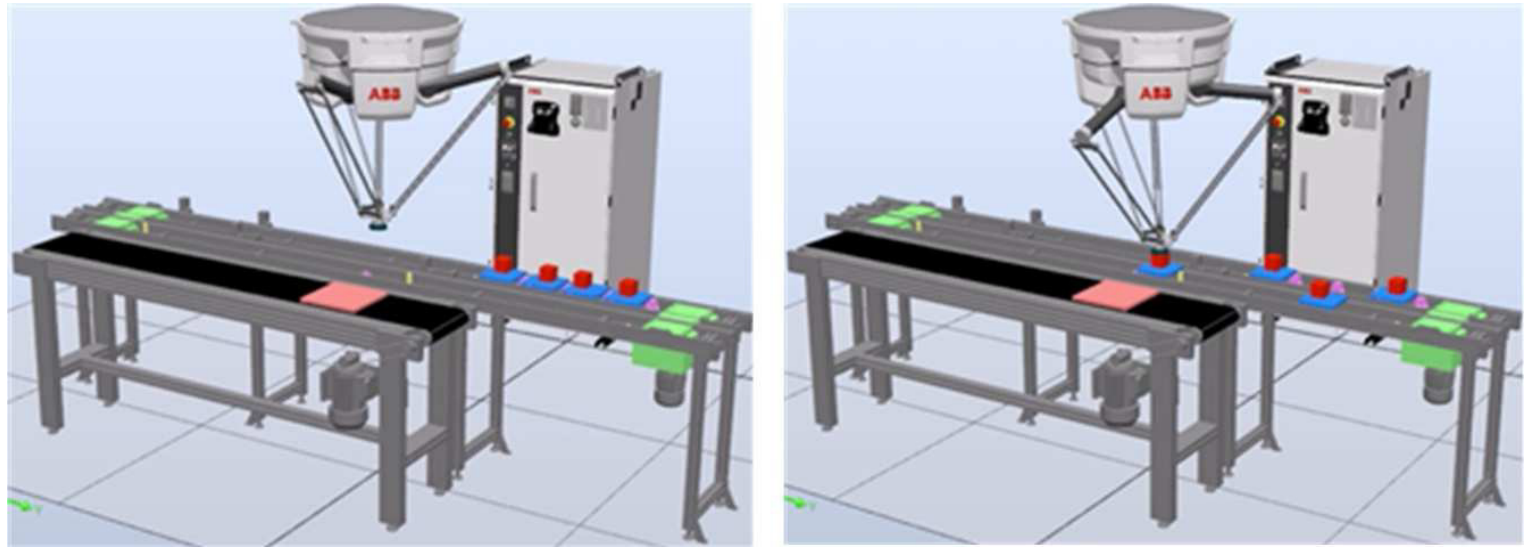

Fig. 5. Start of the Pick \& Place process

After moving the product with the effector to the specified position, the stop gate is deactivated, allowing the empty pallet to move. The empty pallet approaches the second cross conveyor, where it is captured by a sensor and activates the process of moving the pallet through the second cross conveyor, Fig. 6 a.

This procedure is performed a total of 4 times for each product pallet. Each product has its own designated place, where it will be stored, Fig. $6 \mathrm{~b}$ and the empty pallets gradually return to their original positions from where they began their movement at the beginning of the cycle. 

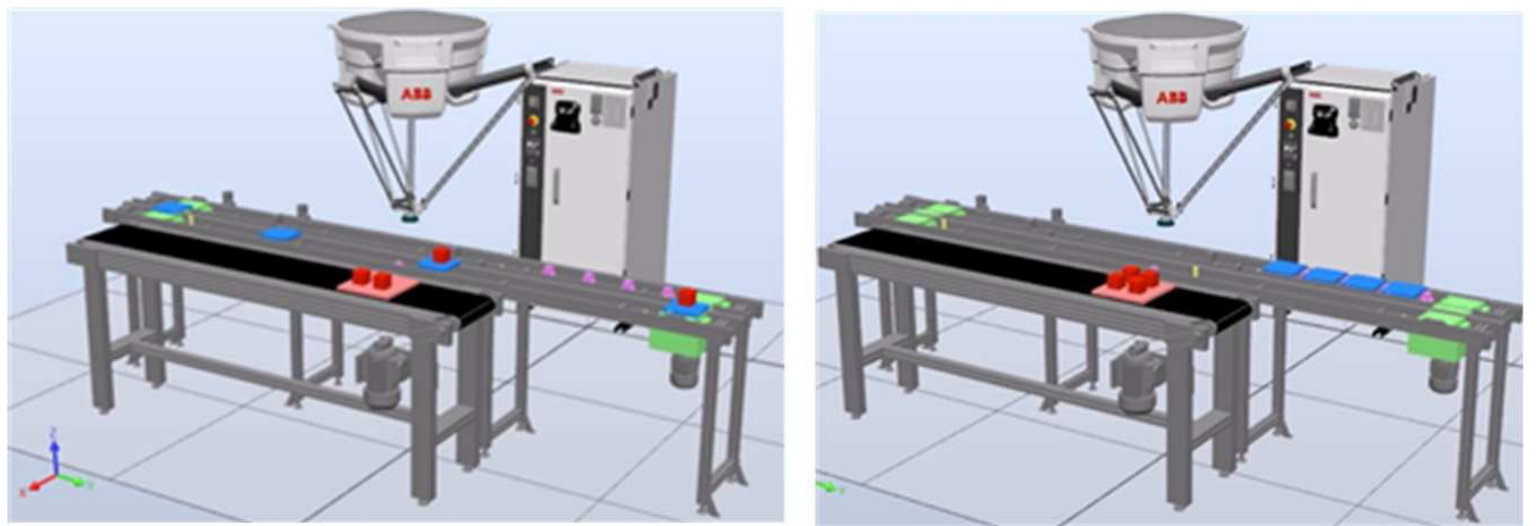

Fig. 6. End of the Pick \& Place process

The robot places the products on a pad, which is placed on a belt conveyor. This conveyor is not included in the handling process, but clearly presents the possibility of incorporating this handling process into larger production processes. The process diagram is shown in Fig. 7.

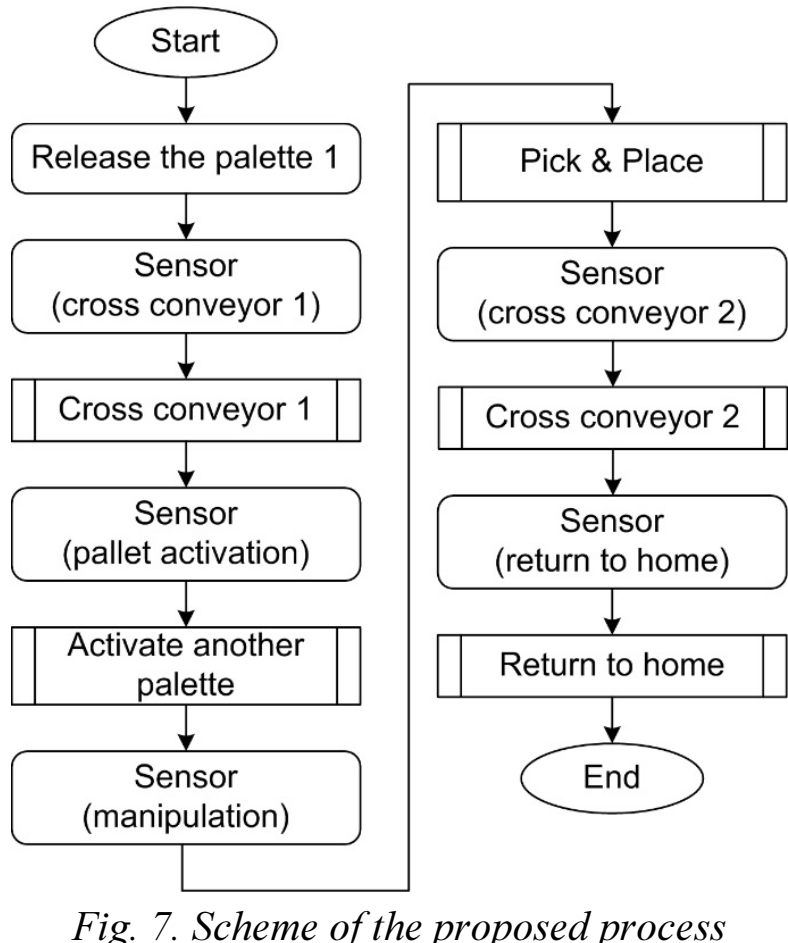

After starting the product, the first palette is released, the movement of which activates the "Sensor" triggering the process (Cross conveyor 1). This process moves the pallet from one longitudinal conveyor to another. After moving the pallet over the cross conveyor, the pallet starts moving along the guide paths of the second longitudinal conveyor and activates the "Sensor" triggering the process (Activate another palette). This process will allow the next product palette to move. The pallet reaches the handling point, where the sensor activates a stop gate preventing the pallet from moving. The "Sensor" also sends an instruction to execute the subroutine (Pick \& Place). This process is performed by the IRB 360 robot, which moves the components from the pallet and sends a signal to release the stop gate, which allows the empty pallet to move. After releasing the handling stop, the empty pallet moves towards the next cross conveyor. There it activates the "Sensor", which initiates the execution of the process (Cross conveyor 2). This process is identical in structure to the process cross conveyor 1 . After moving through the cross conveyor, the pallet is allowed to move on the original longitudinal conveyor, where with the help of the "Sensor" activating the process (Return to home) the pallet stops at the end stop. 
TECHNICAL SCIENCES AND TECHNOLOGIES

The view of the realized workplace is shown in Fig. 8.

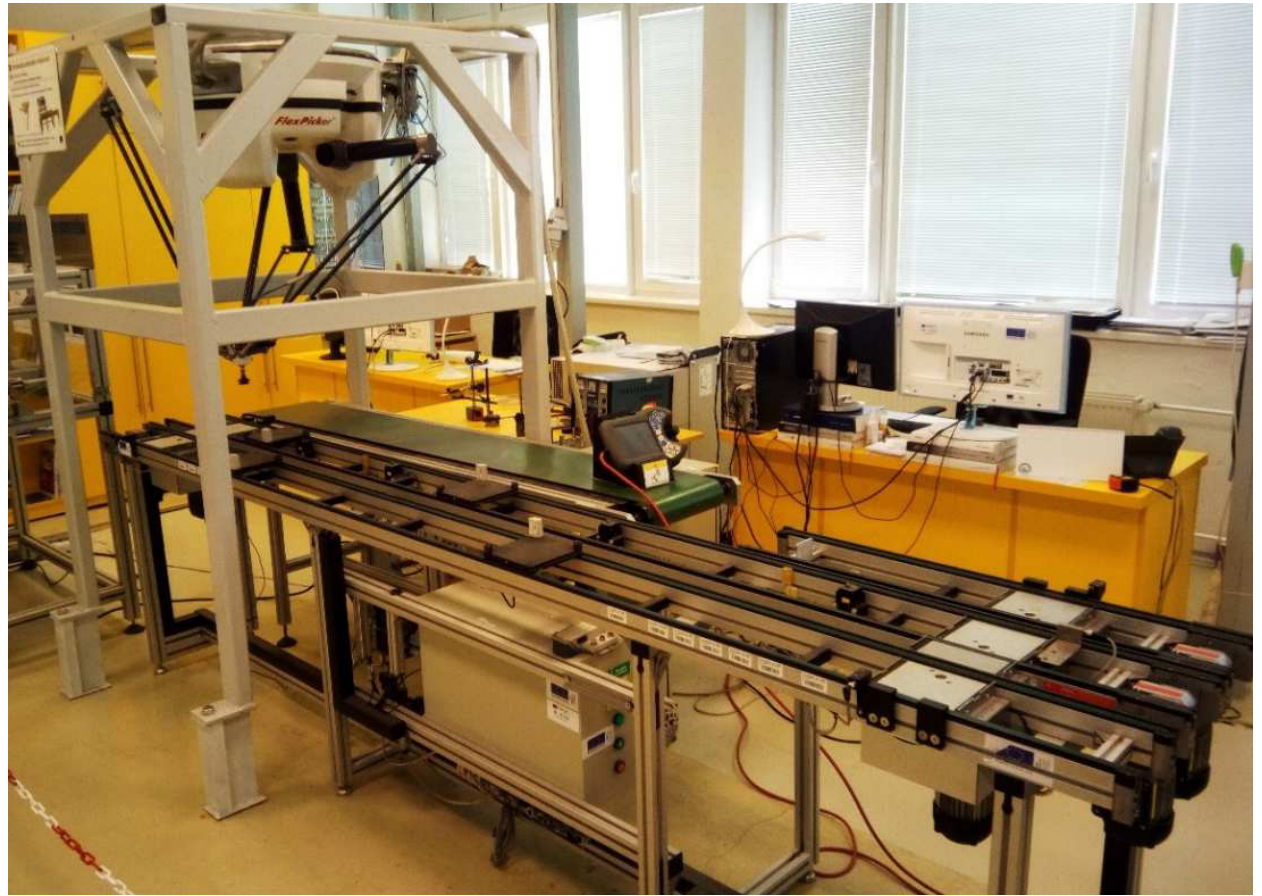

Fig. 8. Realized workplace

In order for the handling process to be performed correctly, it is necessary to ensure proper communication between all peripherals of the workplace. In Fig. 9 shows the interconnection of all control elements and devices involved in the handling process.

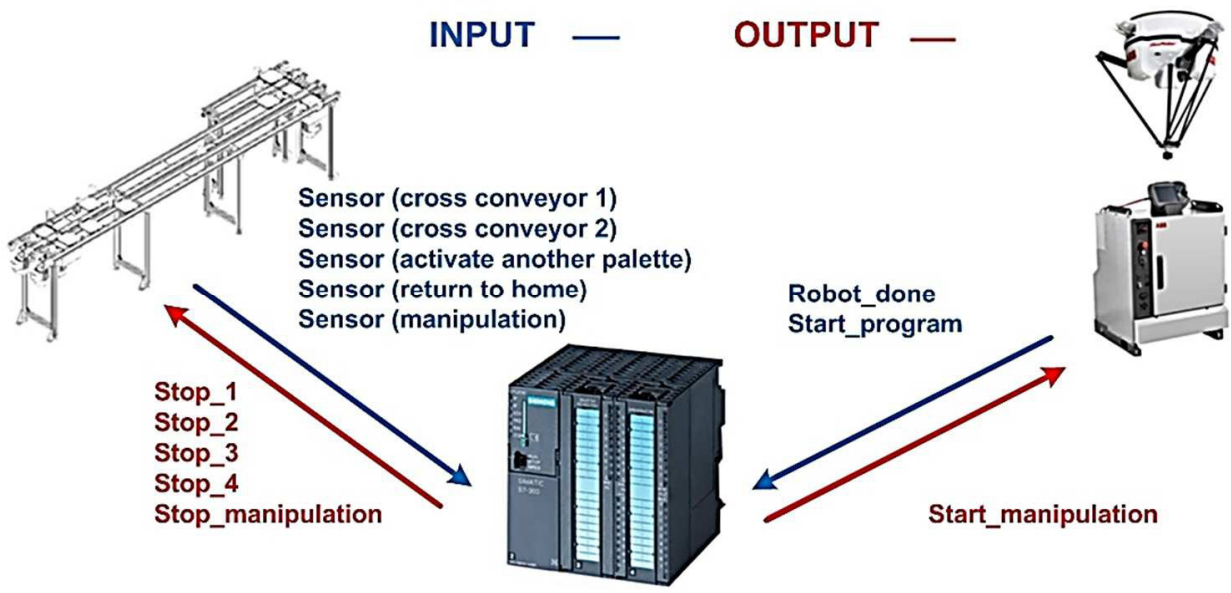

Fig. 9. Inputs and outputs interconnection structure

The inputs are responsible for sending signals from devices located on the conveyor or robot to the PLC. Based on the inputs entered into the PLC, the entire program structure and logic of the entire process is controlled. It is responsible for activating the outputs, which are sent back to the periphery of the conveyor or to the robot [8].

Conclusions. This article shows an example of the handling process with a modular conveyor and the IRB360 Flexpicker robot. The process is relatively simple and allows connection to various other processes or components. The conveyor was equipped and controlled by a Siemens S7 / 300 PLC, which communicated with the IRC5 control system. The IRC5 system, in turn, was responsible for controlling the IRB 360 robot. 
The simulation in Robot Studio helped to visualize the whole manipulation process, in which all controlled elements are shown. The software solution of this process also offers flowcharts of individual threads as well as Ladder Logic diagrams controlling of PLCs.

The handling process consisted of 4 pallets with products whose movement was gradually activated to ensure sufficient spacing. These products were moved to a predetermined location using an IRB 360 robot. Subsequently, the pallets returned to their original position. The transfer between the longitudinal conveyors was ensured by transverse conveyors.

For the needs of the handling process, it was necessary to modify the modular conveyor and implement inductive sensors recording moving pallets and stop gates, which allowed to stop the pallet at a predetermined place and release it based on the needs of the handling process.

Acknowledgements. This article was created thanks to the KEGA project support: 010TUKE-4/2020 - Implementation of new knowledge and innovative approaches to the process of teaching robotics in line with Industry 4.

\section{References}

1. Hajduk. M., et al. (2018). Principles of Formation of Flexible Manufacturing Systems, In: Technical Gazette, Vol. 25, No. 3 (2018), s. 649-654, ISSN 1330-365.

2. Semjon, J., et al. (2018). Comparison of the delta robot ABB IRB 360 properties after collisions, In: Communications - Scientific Letters of the University of Zilina, Vol. 20, No. 1 (2018), s. 42-46. ISSN 1335-4205.

3. Delta Parallel Robot. http://www.parallemic.org/Reviews/Review002.html.

4. ABB IRB 360. https://new.abb.com/products/robotics/en/roboty/irb-360.

5. Bosch Rexroth. TS-1 Transfer System. 2020. https://www.boschrexroth.com/en/xc/products/product-groups/assembly-technology/topics/transfer-systems/transfer-system-ts-1/index.

6. Bosch TS1 Transfer System. version 2018. http://www.boschrexroth.com/various/utilities/mediadirectory/index.jsp?publication $=$ NET\&language $=$ en-GB\&ccat $\mathrm{id}=40460 \&$ remindCcat $=$ on .

7. Siemens Simatic S7/300 Manual. 2017. https://cache.industry.siemens.com/dl/files/629/ 8859629/att_55794/v1/s7300_module_data_manual_en-US_en-US.pdf.

8. Semjon, J., et al. (2019). Programovanie priemyselných robotov II, 1. vyd. Košice : Technická univerzita v Košiciach. 2019. 126 s. [CD-ROM]. ISBN 978-80-553-3418-9.

УДК 621.8

\section{Ян Семйон, Мартін Фуфал, Мартін Кочан \\ ПРОЕКТУВАННЯ ПРОЦЕСУ ОБРОБКИ НА РОБОЧОМ МІСЦІ 3 РОБОТОМ АВВ ТА МОДУЛЬНИМ КОНВЕСРОМ}

Актуальність дослідження. Наразі використання роботизованих операиій Pick \& Place у промисловості набуває дедалі більшого значення завдяки збільшенню продуктивності прачі на робочому місиі. Впровадження таких робототехнічних робочих місиь у харчовій промисловості, де необхідно обробляти велику кількість продуктів, дозволяе підтримувати конкурентоспроможність виробників даної продукиії. Можливість проводити демонстраиії та тренінги на робочих місиях, які не є безпосередньо частиною виробництва, дозволяє студентам та робітникам випробувати иі процеси без необхідності зупиняти виробництво.

Постановка проблеми. Метою є розробка функціонального робочого місия, завданням якого буде реалізаиія демонстраиій роботи на робототехнічному робочому місиі. Спроектоване робоче місие також може викристовуватись у навчальному процесі, де студенти матимуть можливість вдосконалити свої знання з програмування завдань Pick \& Place з використанням паралельного робота. Одночасно студенти зможуть програмувати логіку руху піддону на модульному конвеєрі та синхронізувати цей рух із рухом робота.

Аналіз останніх досліджень і публікацій. Автоматизаиія чи роботизаиія неможливі без використання сучасних конвеєрних систем. Тому необхідно постійно намагатися вдосконалювати сучасні системи для підвищення їхньої продуктивності при збереженні необхідної якості. Цього можна досягти не тільки за рахунок оптимізації процесів, але й за допомогою сучасних модульних конвеєрних систем.

Виділення недосліджених частин загальної проблеми. Підвищення компетентності прачівників та студентів у програмуванні роботизованих робочих місиь покращує їх використання на ринку праці. Цього неможливо досягти лише теоретичною підготовкою, необхідно мати справжні навчальні робочі місия, обладнані відповідною технологією. 


\section{TECHNICAL SCIENCES AND TECHNOLOGIES}

Мета дослідження. Метою є проектування робототехнічного робочого місия, щзо забезпечить збільщення потенціалу співробітників чи студентів та дозволить розвинути їхнє творче мислення. Використання запропонованих об'єктів для маніпуляиій має лише демонстраційний характер і передбачає, що здобувачі вищої освіти самостійно під час навчального прочесу запропонують власне конструктивне рішення иієї проблеми.

Виклад основного матеріалу. Впровадження паралельних роботів у різні операиії постійно збільшується. Тому підготовка відповідних робітників для оптимального використання робототехнічних робочих місиь дуже важлива, враховуючи перехід на Industry 4.0.

Висновки відповідно достатmі. Описано модифікаиію модульного конвеєра для потреб робототехнічного робочого місия, оснащеного паралельним роботом. Робоче місие оснащене роботом IRB 360/3 - 1130, модульним транспортером Bоsch, оснащеним піддонами, і стрічковим транспортером власного виробництва. Паралельний робот оснащений присоскою, що дозволяє переміщувати деталі вагою до 300 г. Запропонований прочес обробки передбачає перенесення деталей у формі куба з модульного на стрічковий конвеєр. При проектуванні робочого місия потрібно було замінити пошкоджений блок управління в модульному конвеєрі, оснастити конвеєр системою додаткових датчиків $i$ запрограмувати робоче місие. Запропоноване робоче місие може бути використано у якості демонстраиійного робочого місия в університеті, а також для навчання здобувачів вищої освіти програмуванню роботів та модульних конвеєрів.

Ключові слова: робот; програмування; конвеєр; піддон.

Рис.: 9. Табл.: 1. Бібл.: 8 .

Jan Semjon - Associate Professor, PhD, Technical University of Kosice, Faculty of Mechanical Engineering, Department of production systems and robotics (Park Komenskeho 8, 04200 Kosice, Slovakia).

E-mail: jan.semjon $@$ tuke.sk

Scopus Author ID: 55571411200

Martin Fufal - Student of engineering studies, Technical University of Kosice, Faculty of Mechanical Engineering, Department of production systems and robotics (Park Komenskeho 8, 04200 Kosice, Slovakia).

E-mail: martin.fufal.student@tuke.sk

Martin Kocan - Student of PhD studies, Technical University of Kosice, Faculty of Mechanical Engineering, Department of production systems and robotics (Park Komenskeho 8, 04200 Kosice, Slovakia).

E-mail: martin.kocan.student@tuke.sk 